\title{
International tax, regulatory arbitrage and the growth of transnational corporations
}

\author{
Sol Picciotto*
}

This paper traces the history of international corporate taxation, discusses how transnational corporations (TNCs), through their tax advisers, have helped to shape the system, and suggests that this is important in understanding the development of TNCs. It argues that a key competitive advantage of TNCs is their ability to exploit differences in corporate tax rules, as a form of regulatory arbitrage, which is facilitated by the inadequate coordination of those rules. It focuses on the divergence between the understanding in business, economics and international studies that TNCs are unitary firms and the principle which has increasingly hardened in international tax rules, especially on transfer pricing, that the various affiliates of TNCs in different countries should be treated as if they were independent entities dealing with each other at arm's length. It argues that this facilitates tax avoidance, which is one of the strategies of the exploitation of regulatory differences, or regulatory arbitrage, which has contributed to the growth and oligopolistic dominance of large TNCs. While claiming that they merely obey the laws of each country where they do business, TNCs have taken advantage of their global reach to mould laws and normative practices, and develop structures taking maximum advantage of the loose coordination of global governance regimes.

Keywords: arm's length principle, BEPS, formulary apportionment, transnational corporations, tax avoidance structures

\section{Tax and transnational corporations}

\subsection{The divergence between tax rules and business reality}

Tax is at the centre of the relationships between TNCs and States, yet there has been surprisingly little attempt to examine the interaction between TNCs and the international tax system. There has been a stark divergence between the underlying

\footnotetext{
* Sol Picciotto is Emeritus Professor, Lancaster University; Senior Fellow, International Centre for Tax and Development (ICTD); Visiting Professor, University of Warwick; s.picciotto@lancs.ac.uk. I am grateful to colleagues at the ICTD for their support, and especially to Michael Durst for his insights and comments; the paper was also greatly improved thanks to comments and suggestions from Peter Muchlinski, Jeffrey Owens, and Bruno Casella.
} 
principles of international tax rules, and the academic and policy discourse on TNCs in the fields of international business, political science, economics and even international law. In all these fields, it is axiomatic that TNCs behave as unified firms under central direction. There is certainly plenty of discussion in the international business literature of degrees of decentralization, conglomerates and concentration, group structures (divisionalization, regionalization), the balance between strategic direction and operational management, and other problems of managing complex multinational corporate empires. Yet the unquestioned assumption is that the TNC is a unitary business enterprise and a single political actor. In contrast, international tax rules have become based on the legal fiction that each national tax authority should treat the local affiliates of a TNC as if they were independent entities, dealing "at arm's length" with the other members of the corporate group.

This paper explores the reasons for, and consequences of, this strange divergence. The issues go beyond international tax: there are similar problems in other areas of economic regulation, such as prudential requirements for banks. At root, they lie in the central tension that States are national while TNCs operate globally. Yet this should not be overstated. Although State power is in principle territorial, a State's jurisdiction can extend more widely (Picciotto, 1983; Picciotto 2011, pp. 34-50). As is well known, the US, in particular, makes extensive claims to extraterritorial jurisdiction over both US-based TNCs and others wishing to do business in the US. Conversely, although TNCs operate globally, with few exceptions they have an ultimate home State, as the term transnational suggests.

One source of the difficulty for governments in regulating TNCs is the fiction of corporate personality. A company is formally a separate legal person, even if it is a $100 \%$-owned subsidiary of another. However, the law is sufficiently flexible to be able to disregard this fiction through doctrines on "lifting the corporate veil", "single enterprise" or "organic unity" (Blumberg, 1983; Hadden, 1993). Indeed, a number of countries have adopted tax consolidation regimes at the national level (Ting, 2013). Thus, whether the concept of a separate corporate personality should be accepted or disregarded in any particular context is ultimately a political question.

The adoption of an enterprise approach is easier at the national than at the global level. Traditionally, international law is public law governing the relationships between States, whereas corporations are private legal persons and hence governed by national laws. However, the rapid growth of TNCs, especially since the 1950s, highlighted the tension between the global reach and visibility of TNCs and this dualist hierarchy of national and international law. The increasing size and importance of TNCs made them a prime target for regulation, in both home and host States, exposing them to multiple and sometimes conflicting regulatory requirements, which came to the fore in the 1960s. In a period of lively debate, a variety of proposals were advanced. Perhaps most radically, George Ball, one-time US Under-Secretary of State and United Nations representative, and subsequently 
Chairman of Lehman Brothers International, proposed that TNCs should be treated as "citizens of the world" (Ball, 1967, p. 29; see also Ball, 1975). He argued that this was needed to resolve the "inherent conflict of interest between corporate managements that operate in the world economy and governments whose points of view are confined to the narrow national scene" (Ball, 1967, p. 28).

Ball's suggestion did not gain much traction among TNC leaders. Instead, TNCs have preferred to take the position that they obey the laws of every country where they do business. This of course belies the reality that they are global actors, with the power to shape both national and transnational law. Avoiding designation as global citizens blunted the pressures in the 1970s for them to be subject to international obligations. This dissipated into the formulation of a variety of essentially voluntary codes of conduct.

At the same time, TNCs have been successful, by strategic lobbying, in securing rights and protections entrenched in national law, through international investment agreements (IIAs) and similar treaty networks. Tax treaties are even more effective in this respect than IIAs, in that their provisions normally are incorporated automatically into domestic law, which is not usually the case for IIAs. This creates a special tax regime within national laws for international income, so that the ability of States to change international aspects of their tax laws is constrained by international tax rules. The provisions of IIAs do not generally have this direct legal effect, but they do generally include international arbitration procedures for enforcing the rights of investors. These procedures have been used in a number of tax-related cases, which raises questions about the relationship between the two systems. Similar arbitration procedures are now being introduced in tax treaties, which would provide a double lock binding States to the international tax regime (Picciotto, 2016).

By contrast, the weakness of international tax coordination has meant that national laws for taxing TNCs have remained ineffective, largely because they are generally not based on the business reality that TNCs are unitary enterprises. The remainder of this section outlines how this came about, focusing mainly on the rules on transfer pricing, while showing that the issue is much broader than generally understood by this term. ${ }^{1}$ The next section discusses how TNCs have exploited those rules and how this has affected their growth and structures.

${ }^{1}$ A fuller account is provided in Picciotto, 2018. 


\subsection{The development of tax rules for TNCs}

International tax rules originated in the work of the League of Nations in the $1920 \mathrm{~s}$ (Picciotto, 1992, ch. 1.4; Jogarajan, 2018). This laid the groundwork for the system that grew rapidly in the second half of the last century, built around a network of bilateral treaties, based on a model convention (Picciotto, 2013). The treaties allocate rights between States to tax income and capital, aiming mainly to facilitate international investment by preventing double taxation. Only more recently have the guardians of international tax begun to pay serious attention to how the rules can also ensure that companies pay tax where they have real economic activities.

The first model conventions were formulated through the League of Nations and agreed at a conference in 1928. At that time, international investment flows consisted mainly of portfolio investment through bonds and equity participation. Hence, it was agreed to allocate the primary rights to tax business profits (active income) to the country where the business was located, while the passive returns on investment (interest, dividends) should be taxed mainly in the country of residence of the investor. ${ }^{2}$ This allowed a host country to tax the business profits of the local subsidiary of a TNC, or of a branch if it met the threshold for taxable presence, defined as a "permanent establishment".

National tax authorities were already aware of the difficulty of determining the appropriate level of profits of the various affiliates of a TNC. The issue was put succinctly to the UK Royal Commission on Income Taxation in 1920 by Sir William Vestey, co-founder of a global food firm with cattle ranches in Argentina and worldwide beef sales:

In a business of this nature you cannot say how much is made in one country and how much is made in another. You kill an animal and the product of that animal is sold in 50 different countries. You cannot say how much is made in England and how much is made abroad. ${ }^{3}$

The issue was investigated in a study carried out for the Fiscal Committee of the League, coordinated by Mitchell D. Carroll (the US representative), with national reports from 27 countries (League of Nations, 1933). The Carroll report found that, although national tax authorities necessarily began from the accounts of the entities within their jurisdiction, they generally had broad powers to adjust these

\footnotetext{
2 The distinction at the time was between "personal" taxes, such as the general income tax, and "impersonal" taxes, which in many countries were schedular, i.e. distinguished between different kinds of activity, including industrial and commercial business; for more detail see Jogarajan, 2018, ch. 3.

${ }^{3}$ UK Royal Commission on Income Tax 1920, Minutes of Evidence and Final Report, CMD 615, p. 452, Question 9460. Having identified the weaknesses of international tax coordination, the Vesteys became pioneers of international tax avoidance. Attempts to defeat the structures they established to avoid tax resulted in long-running legal battles in the UK in the 1930s (Picciotto, 1992, pp. 100-102; Knightley, 1993), and challenges in the Congress in Argentina in 1934 (Grondona and Knobel, 2017, p. 10).
} 
accounts if the entities were under common ownership or control. This was seen as necessary to prevent "diversion" of income, recognizing that such entities were not independent. Resulting from this report, a provision was incorporated into tax treaties from 1935 to allow national tax authorities to adjust the accounts of related entities to ensure that their profits were in line with those of independent enterprises. Carroll reported that two methods were generally used: "fractional apportionment" of the global profits of the TNC, and "empirical" methods, attributing to the local affiliates a level of profit similar to that earned by comparable local firms (League of Nations, 1933, p. 12). This contradictory principle provided an uncertain foundation since, although the power to adjust accounts was premised on the understanding that related entities are not independent, the criterion for attributing profit was a comparison with similar independent enterprises. Table 1 outlines the successive stages of the attempts to apply this principle.

When it was formulated, the principle aimed to ensure an acceptable allocation of the profits of TNCs, focusing on the level of income declared. At that time, there was no internationally agreed guidance on how it should be applied. In the US, a statutory provision of 1928 gave tax authorities broad power to adjust the accounts of related entities as necessary "clearly to reflect the income", and this provision has remained the same to this day, with only one amendment in 1986. Other countries enacted similar provisions, notably France in 1933, which has also remained unchanged, despite a recent recommendation to narrow its scope (France, Ministry of Finance, 2013), or used general anti-abuse rules. US regulations in 1935 defined the standard as that of "an uncontrolled taxpayer dealing at arm's length with another uncontrolled taxpayer", which has since been referred to as the arm's length principle (ALP). However, for 40 years US court decisions considered that the allocation of profits should be "fair" or "reasonable", and the ALP did not require any comparison with actual or hypothetical transactions between independent entities (Avi-Yonah, 1995).

The term "transfer pricing" was not used in the context of international tax until relatively recently. It emerged in the economic and accounting literature to refer to the criteria and strategies for pricing internal transfers between related entities within an integrated TNC group for management purposes. A seminal paper by Hirshleifer (1956) analyzed the strategy for pricing transfers of goods, which would lead profit centres to make decisions yielding the maximum profit for the firm as a whole. A literature survey in 1974 explained that "[t]he rationale for an internal pricing system is motivated by the presumed behavioural advantage of operating autonomous units in a decentralized firm in the absence of externally determined market prices for the internally exchanged commodities" (Abdel-khalik and Lusk, 1974). A study in the early 1980s showed that the policies adopted by TNCs surveyed reflected management strategies, notably the type and degree of integration in the firm (Eccles, 1985). Tax was not mentioned in these studies, except for the possibility 


\section{Table 1. From profit allocation to transfer pricing adjustments}

\section{National measures}

\section{5-1968}

Allocation of income of

TNCs, based on broad

powers to adjust accounts

\section{8-1988}

Focus shifts to adjustment

of transaction prices,

also applied to joint

factors of production

(capital, intangibles, risk

management), instead of

treating them as overhead

costs to be shared.

Application by US states

(e.g. California) of global

formulary apportionment

creates backlash from non-

US TNCs and political furore.

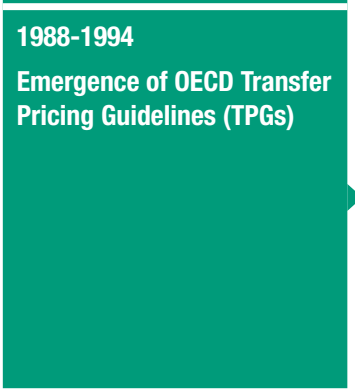

\section{- UK, 1915: can assess related} resident and non-resident entities based on percentage of turnover.

- US, 1928: can reallocate income of related entities "to prevent evasion of taxes or clearly to reflect the income" (now s. 482 of Tax Code); regulations refer to the "arm's length principle".

- France, 1933: can adjust accounts of entities under common control to restore "indirectly transferred" profits (now s. 57 of Tax Code).

- US Transfer Pricing Regulations, 1968: specify comparable uncontrolled price, cost-plus or retail-minus, with "other" methods as fall-back

- OECD Working Party, 1967: rejects US approach, deeming impossible the formulation of general rules for determining an arm's length price.

- Studies for US Treasury, 1973; Congress, 1981; IRS, 1984: show that in practice "comparables" are hard to find, frequent use of other methods. Congress urges Treasury to consider formulary apportionment.

- US Tax Reform, 1986: adds "commensurate with income" test to s.482.

- Treasury White Paper, 1988: proposes a new profit attribution method, creating conflict at the $\mathrm{OECD}$, resulting in a compromise to add the Transnational Net Margin Method (TNMM) and profitsplit methods.

\section{International activities}

- League of Nations model treaties, 1928: State can tax business profits of a resident company and of the "permanent establishment" of a non-resident.

- Carroll report, 1933: finds States use (i) "empirical methods" (e.g. standard profit margin as percentage of turnover), and (ii) fractional apportionment of TNC's global profits.

- League's Fiscal Committee, 1935: adopts model provision allowing adjustment of profits if conditions between related parties differ from those which would have been made by independent enterprises.

- Debate about power of TNCs, including transfer pricing, e.g. of drugs, results in report of UN Eminent Persons on TNCs, 1974. OECD Council calls for report on transfer pricing.

- OECD Committee on Fiscal Affairs Report on Transfer Pricing, 1979: largely recommends approach of the US regulations of 1968.

OECD adopts TPGs, 1995: adds the two new approved methods, but rejects formula apportionment and emphasizes case-by-case analysis. 
Table 1. From profit allocation to transfer pricing adjustments (Concluded)

\section{National measures}

1995-2015

Entrenchment of the TPGs and the independent entity principle.

Regulations based on TPGs adopted worldwide, first

by OECD countries, then emerging economies, and finally developing countries.
- OECD countries adopt regulations, mostly based on the TPGs, though some (e.g. France, US) retain broad statutory power. Only Brazil (1998) opts for a simplified method applying fixed margins. India's adoption of the TPGs (2001) creates a litigation explosion.

- Growth of 'cognitive community' of transfer pricing specialists.

- Base Erosion and Profit Shifting (BEPS) Action Plan includes work on transfer pricing, perhaps going beyond the arm's length principle, though rejecting formulary apportionment.

\section{International activities}

- OECD reviews, 2008-10: further entrench ad hoc approach and focus on transaction pricing and comparables, neglecting profit split.

- Continual increase of international conflicts and the time taken to resolve them.

- BEPS reports, 2015: still emphasize starting from transactions, though with strengthened powers to recharacterize them, adding further uncertainty and complexity.

Sources: Avi-Yonah, 1995; Durst and Culbertson, 2003; Picciotto, 1992, 2018.

of an internal tax used as a managerial strategy. The focus was on the pricing of goods, and the objective was to set prices that would incentivise managers of production units to remain competitive with outside suppliers, while ensuring that the firm retained the advantages of integration.

Concerns about transfer pricing in the context of international tax emerged in the 1970s, on account of two main drivers. The first came from US initiatives to amend the country's international tax rules, begun under the Kennedy administration. US TNCs had been able to finance their rapid expansion in the post-war period through retained earnings, avoiding controls on capital movements, as well as structuring their foreign operations to minimize tax (see Picciotto, 1992, ch. 5, and section 2.1 in this paper).

The government adopted a dual approach in response. First, rules were proposed to tax the worldwide income of TNCs with US parents, by including the business income of "controlled foreign corporations" (CFCs) in that of their parent, while allowing a credit for foreign taxes paid on such income. This approach treats TNCs as unitary enterprises, disregarding intra-firm transactions, thus rendering the terms of such transactions largely irrelevant for tax purposes. Also, it taxes such consolidated profits at the higher of the host or home country rate, thereby removing the incentive for host countries to reduce their tax rate to attract investment by US TNCs. In response to business pressure, the proposals were watered down when enacted by the Congress in 1962, to cover only the "passive" income of CFCs in low-tax countries. 
This put greater weight on the complementary proposals for new regulations on the allocation of income, which were finally enacted by Congress in 1968. These regulations were detailed and prescriptive, aiming to strengthen the ALP and focusing on the pricing of all transactions between related entities, not only physical goods. They specified the use, where possible, of the "comparable uncontrolled price" (CUP) method and otherwise either cost-plus (production costs plus an appropriate profit margin) or retail-minus (the sale price to an unrelated party minus a gross profit margin covering costs and an appropriate profit). However, as a fallback, other methods for allocating income could be used.

This approach, based on finding "comparables" for transaction prices, was widely criticized. It was rejected as unworkable by the OECD Committee on Fiscal Affairs, based on a report by the UK and the Netherlands (OECD, 1967a). US commentators analysing the implications of the regulations for the allocation of taxable profits began to deploy the concept of transfer pricing, generally used transitively and in a pejorative sense. An insightful article by Peggy Musgrave (1972) considered how best to "assign profits of the international business unit among countries according to some consistent and meaningful index of profit-creating capability" (Musgrave, 1972, p. 399). She concluded that "[t]he more extensive are business interdependencies, the more necessary it becomes to take a unitary view of the enterprise and to attribute profits on a formula apportionment basis" (p. 407). Academic opinion generally supported this view, pointing out that TNCs "enjoy considerable freedom from market constraints in setting transfer prices for intercompany transactions in goods and services", and that this can be used for "income shifting" to avoid tax, while there are also "many important non-income tax influences on such decisions" (Anon., 1976, p. 1203). Indeed, studies done for the US Treasury (1973), the Congress (1981) and the Internal Revenue Service (IRS) (1984) showed that true comparables were hard or impossible to find, and the IRS in practice made extensive use of other methods (summarized in Picciotto, 1992, p. 198).

As the criticisms in the US of the transactional approach grew, however, the other OECD countries shifted towards accepting it. This was on account of the second factor that fed concerns in the 1970s about transfer pricing in international tax - the political debate about the power of TNCs. Transfer pricing abuse was identified as a technique used by TNCs to undermine national State regulation, including not only tax but other areas such as exchange controls and technology transfer, notably in the pharmaceutical industry (Lall, 1973), with some highly publicized cases such as that of Hoffmann-La Roche (UK Monopolies Commission, 1973). The United Nations set up a Group of Eminent Persons to produce a report on TNCs, and this included recommendations on taxes: to enforce the ALP and to elaborate rules on transfer pricing, preferably by international agreement (UN, 1974). This task was taken on by the OECD's Committee on Fiscal Affairs. 
In parallel, a major international dispute arose over the application by US states, notably California, of their state taxes by applying formulary apportionment to foreign-owned affiliates on a worldwide basis. This created conflict with European and Japanese TNCs, expanding into those states. They were supported by governments at the highest level, resulting in aversion to formulary apportionment of TNC profits (Picciotto, 1992, ch. 9). This reinforced the view of international tax specialists that a more global approach to the question of allocation of TNC profits would be difficult due to political constraints. Hence, they concluded that it should be dealt with pragmatically, as had the Carroll report in 1933.

It was therefore no surprise that the report on transfer pricing produced by the OECD Committee on Fiscal Affairs (OECD, 1979) recommended an approach largely based on the 1968 US regulations and rejected formulary apportionment. There was no consideration of the broader issue of TNC tax avoidance, particularly the abuse of tax treaties through intermediary companies in tax havens. This had separately been referred to the Committee in 1962 by the US, and a working party of US and Danish representatives had reported on measures to counter the use of "base companies", including provisions such as the US rules on CFCs (OECD, 1967b). No recommendations emerged at that time, and these issues were not mentioned in the report on transfer pricing of 1979. Reports on the use of base and conduit companies were eventually issued in 1986 (see section 2.1).

Continuing concern in the US about the ineffectiveness of the transfer pricing regulations led the Congress to amend section 482 (for the first time since 1928), by adding a requirement that payments for intangibles transferred to foreign affiliates of US TNCs should be "commensurate with [the] income" they generated. It also urged the Treasury to carry out a full review of transfer pricing. Avoiding international controversy, the Treasury set its face against formulary apportionment, but it restricted use of the CUP to exact comparables and proposed a comparable profit method to apply a benchmark rate of return to capital assets or another suitable base (Durst and Culberston, 2003, pp. 71-2). However, this would attribute relatively low profit margins to foreign affiliates of US TNCs, so it led to conflicts at the OECD in the early 1990s.

The OECD Transfer Pricing Guidelines (TPGs), finally produced in 1995, recommended five transfer pricing methods, including a version of the US's comparable profits method, called the transactional net margin method (TNMM). They also provided for a profit-split method, which could be especially useful where comparable transactions between independent parties could not be identified or where the related-party operations were highly integrated. This would allow apportionment to affiliates in host countries of some of the profits from economies of scale or other synergies. Although clearly involving apportionment, the Guidelines described it as a "transactional" method, and firmly rejected apportionment based on a general formula. 
The TPGs emphasize the need for a case-by-case analysis to choose the most appropriate method and determine how to apply it. This retained flexibility for national tax authorities, but it also put tax authorities on a very unequal footing with TNCs' tax planners.

\subsection{The arm's length principle: global standards and national sovereignty}

The approach thus adopted preserves a nominal sovereignty for each national administration to decide how to adjust the accounts of local affiliates of TNCs, while avoiding overt public debate over the criteria for the allocation of profits. Determining such criteria has always been regarded by technical specialists as too contentious to be done by public or political methods. Hence, transfer pricing has become the preserve of a closed community of technical specialists.

The TPGs require an analysis of the "facts and circumstances" of each case, to identify the functions performed, assets deployed, and risks assumed by each entity, referred to as "functional analysis" (Andrus and Collier 2017: para. 3.26 et seq.). Hence, the transfer pricing methodology must be tailored to each individual taxpayer. Indeed, the main reason given for rejecting "global formulary apportionment" is that it would allocate the global profits "on the basis of a predetermined and mechanistic formula"; this is, however, distinguished from "application of a formula developed by both tax administrations in cooperation with a specific taxpayer or [multinational enterprise] group after careful analysis of the particular facts and circumstances" (OECD, 2017, para. 1.17). This pragmatic approach depoliticizes the issue by converting it from one to be addressed directly in terms of broad principle to a technical one to be dealt with on a case-by-case basis.

This ad hoc approach creates considerable administrative problems, as well as uncertainty, for both taxpayers and administrations. These fall more heavily on tax authorities, due to the disadvantages of information asymmetry. Although the formal legal burden is usually on the taxpayer to justify its accounts, in practice the reverse is the case. If the taxpayer prepares and documents a transfer pricing structure, usually with the help of a specialist team of advisers, the tax authority cannot challenge it without carrying out a detailed analysis. Thus, the beneficiaries have been the growing legion of transfer pricing specialists.

The problems caused by the ALP have been exacerbated by its extension beyond the transfer of physical goods, begun by the US regulations of 1968 and adopted and extended in the 1995 Guidelines. This extension meant that joint factors of production (capital, technology, central services, risk management) should not be treated as overhead costs to be shared, but transfers to be priced by reference to the ALP (Langbein, 1986). These issues continue to confound the application of the ALP (Andrus and Collier, 2017, ch. 6), since they are core centralised functions 
in TNCs. TNCs have a central treasury function that closely controls the allocation of funds within the group. Research and development, though taking place throughout the firm, is closely coordinated, and technology and know-how are shared. Risk is ultimately borne by the parent company and its shareholders, who always, in practice, stand behind the liabilities of wholly owned subsidiaries. From the perspective of studies of international business, it makes no sense to treat the responsibility for such activities as being genuinely borne by different legal entities within a TNC corporate group. Yet the entrenchment of the ALP normalized this understanding for tax purposes.

The TPGs are far from legally binding (see Picciotto, 2018), but they have attained a canonical status. Their publication in 1995 led to an increasingly widespread adoption by countries of transfer pricing measures, becoming a veritable torrent from 2010, so that now such rules are in place in almost every country worldwide. ${ }^{4}$ The ripple effect is understandable. Since countries want to be seen to defend their tax bases, but not in ways that might significantly deter foreign investment, the adoption of a global standard seems politically sensible. The announcement of new rules, and especially increased enforcement by any State, would lead TNCs to take steps to ensure that their accounts would stand up to this scrutiny, which is likely to result in a short-term increase in tax revenues for that State. Other countries naturally fear this increase in revenues would be at their expense, so they follow suit. Nevertheless, although it is understandable that OECD countries in the early years after 1995 should have followed the consensus expressed in the TPGs, ${ }^{5}$ it is more difficult to explain the continuing adherence to them, and the policy advice that continues to be given to developing countries that they should follow the OECD approach, despite its evident limitations.

Clearly, TNCs have greatly benefited from the establishment of the ALP as a global standard. It allows them to proclaim their adherence to the rules as good citizens in every country where they do business, while dominating the arenas where those rules are defined and interpreted - nationally and supranationally. Within this overarching structural determinant, the widespread influence of the TPGs seems attributable to three main factors.

\footnotetext{
${ }^{4}$ Surveys are regularly published by the Big Four accounting and consultancy firms; a database under development is on file with the author.

${ }^{5}$ With the notable exception of Brazil, see further Picciotto, 2018.
} 
First is the power generated in a policy community by the formulation of techniques for professional practice. ${ }^{6}$ Especially where a market exists or can be created for such professional practices, enormous investments pour into their refinement and dissemination. Certainly, the field of transfer pricing quickly became an important field of specialization from the 1980s, with an increasing proliferation of specialist courses and publications, and the creation of practice groups in the large global legal and corporate advice firms, as well as the emergence of smaller boutiques offering more specialist techniques such as micro-economic analysis. The epistemic perspectives created in such a field of private practice tend to also pervade the public sector, due to the intermingling of personnel in professional interactions, and career paths through the "revolving door" between the private and public sectors.

The path dependence of policy formation created by these investments in intellectual capital makes it very hard to reform such a field, unless it is disrupted by an exogenous shock. Yet dominant views are strongly protected from such shocks as a result of the increasing gap between the simplistic slogans that dominate public discussion and the technicist terms in which specific policy prescriptions are discussed. ${ }^{7}$ Politicians and others who dominate policy debates in public arenas either have little understanding of the technical details, or gloss over them in their public pronouncements. The difficulty for outsiders to understand the issues is exacerbated by the cloak of secrecy due to the tight confidentiality rules, arcane jargon and increased complexity created by professional practices.

Second, this type of closed policy community can become institutionalized in ways which make it hard for external political pressures to change. Again, transfer pricing is a good example, since its practice became embedded in the OECD, which is the main intergovernmental organization for the formation and diffusion of business and corporate regulatory practices. The OECD has special power in such fields because, although an intergovernmental organization, its work is considered nonpolitical. It operates by developing a consensus around such governance practices, which provide the underpinning for formal international norms, some of which it also formulates. Once its Committee on Fiscal Affairs (CFA) became the driver for developing the formal tax treaty framework in 1956, the OECD became the main institutional focus for managing the tensions generated by that system. The central concern of governmental specialists, going back to the 1930s, has been

\footnotetext{
${ }^{6}$ This analysis draws on a variety of social science research efforts on the shaping of markets through professional practices: some based on social studies of science emphasising 'performativity' (e.g. MacKenzie, 2006), and others in international political economy on the role of epistemic communities or cognitive capitalism (e.g. Adler and Haas, 1992; Adler and Bernstein, 2005; Dezalay and Garth, 2001), as well as work on the interpretive practices of lawyers (see Picciotto, 2015). The role of 'cognitive capture' in the development of the ALP in transfer pricing has also been pointed out by Langbein (2010).

${ }^{7}$ For a discussion of technicism in global governance, see Picciotto, 2011, pp. 23-24.
} 
to attempt to prevent public disagreement about the allocation of profits of TNCs, by maintaining some consensus on the apparently non-political techniques for dealing with the issue. Whenever political concerns have been awakened about the taxation of TNCs, the task of developing solutions has been passed to the OECD. ${ }^{8}$ This occurred in 1976, 1990 and 2012, and each time the technical specialists responded with further refinements to the ALP.

Third, the formulation of the normative understandings of such professional communities in documents such as the TPGs enables their rapid global diffusion. Thus, the TPGs and any changes adopted to them, once rubber-stamped by the OECD Council, can be effective immediately, unlike changes to a model treaty, which need governmental approval and bilateral negotiation. This is what makes such specialist communities and international soft law central to global governance (Picciotto, 2011).

These factors perhaps help to explain the central paradox of transfer pricing: the almost universal acceptance of the ALP, despite its known and often admitted defects, together with the continuing elaboration of increasingly complex and imprecise methods for its application in practice. The TPGs are far from providing a clear and practical basis for transfer pricing. They result from discussions among the government transfer pricing delegates to Working Party 6 of the OECD, and their style is discursive, that of a report rather than rules or even guidelines for application. Nevertheless, they specify the approach that must be adopted, although leaving considerable leeway for choosing among the five approved methods and how they should be applied. In practice, enforcement has been restrained, especially in poor countries reliant on inward investment, by two factors: the enormous resources needed and the concern not to damage inward investment.

On account of their subjective nature, the introduction of transfer pricing rules based on the TPGs and their increased enforcement, especially in the past 10 years, has led to an increase in international tax conflicts (the majority about transfer pricing), and in the time taken to resolve these disputes (Picciotto, 2016).

\footnotetext{
8 The CFA operates through Working Parties of member State representatives, the most important being WP 1 on tax treaties and WP 6 on transfer pricing. The OECD officials providing support are often seconded from or former members of national tax authorities, but some come from the private sector, or more often go there after a stint at the OECD. Notably, the international law firm Baker McKenzie recruited the top two OECD officials responsible for transfer pricing to its international tax department in 2011, one who had gone from the same firm to the OECD in 2005, and was earlier in the US Treasury. In 2018, the official who had been divisional head for tax treaties and transfer pricing (for only two years) left, and quickly joined a top Washington DC law firm, and it was reported that his successor is a former head of global tax at Amazon.
} 


\section{Exploitation of the rules by TNCs and reform attempts}

The failure to adopt a coordinated international approach to TNC taxation encouraged TNCs to refine their exploitation of the independent entity principle. This resulted in the creation of complex structures, so that the largest TNC corporate groups have hundreds of affiliates. Analysis by UNCTAD shows that although only $1 \%$ of TNCs have over 100 affiliates, these TNCs account for over $60 \%$ of value added by TNCs, and that the largest 100 TNCs have some 55,000 affiliates between them (UNCTAD, 2016, pp. 134-5).

\subsection{The evolution of avoidance structures}

Basic tax avoidance techniques consisted of creating "base companies" in lowtax jurisdictions or tax havens, to own assets such as intellectual property rights or act as financial or servicing hubs. The deduction of royalties, interest and fees reduces the taxable business profits of operating affiliates, and those payments are channelled through conduit entities in countries with suitable tax treaties (to reduce withholding tax at source) to be retained tax-free by the base company (see Figure 1).

Such "stepping stone" structures were described in reports from the OECD's Committee on Fiscal Affairs on base and conduit companies in 1986 (as mentioned in section 1.2). These reports provided suggestions for counter-measures in national law and in treaties, including CFC rules, which led to some OECD countries adopting similar measures. However, these measures were limited and ineffective, the results of business lobbying on key elements such as the definition of "passive" income, ${ }^{9}$ and of competition to attract corporate headquarters. ${ }^{10}$

It is noteworthy that these devices make relatively little use of manipulating the prices of transfers of physical goods, although this can be problematic, especially where the goods embody specialized technology. The central techniques involve relocating the ownership of intangible assets as well as responsibility for financial or service activities. These are obviously easily attributable to an entity located anywhere, so they are sometimes referred to as "mobile", although a better term would be "virtual" since such entities may have few or no employees. Thus, the

\footnotetext{
${ }^{9}$ A key provision in the US law has been the "active finance" exemption, which has been the target of fierce lobbying by US firms, especially General Electric (Gerth and Sloan, 2011).

${ }^{10}$ The US rules were weakened in the 1990s by "check-the-box" regulations, which allowed subsidiaries to be treated as "disregarded" for tax purposes and became totally ineffective after 2006 when Congress enacted a "look-through" rule (US Senate, 2013, pp. 6-7). The UK largely abandoned its CFC regime in 2012, one of several moves in joining in tax competition with countries such as Ireland and the Netherlands.
} 


\section{Figure 1. Basic 'stepping stone' tax avoidance structure}

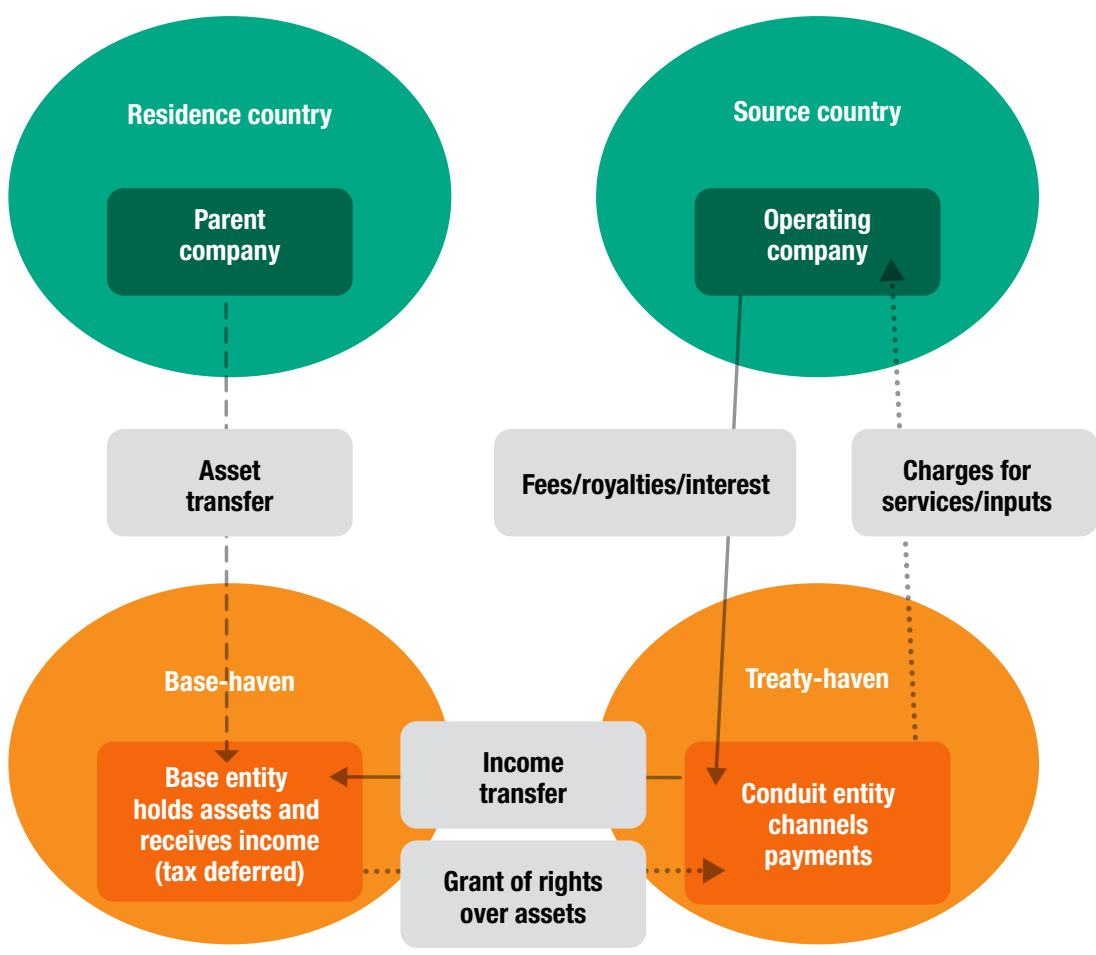

use of "offshore hubs" became a key element in the structures of the largest TNCs (UNCTAD, 2016).

Following the 1995 Guidelines, the design of TNC structures aimed at tax avoidance became even more complex. The Guidelines emphasized the need for a "functional analysis" of TNC groups, and the attribution of profits on the basis of the functions performed by each entity. Hence, tax advisers devised structures that fragmented TNCs' business among different functions, so that key functions that add high value could be attributed to entities whose profits would be lightly taxed. This became simpler as improvements in communications, and then digitalization, made it easier to manage global value chains. Affiliates whose profits are subject to high tax rates are treated as performing "low-risk" production, distribution or even research functions, and are attributed "routine" rates of profit, usually applying a "one-sided" transfer pricing method (cost-plus, resale-minus, or the TNMM). A standard type of structure is illustrated in simplified form in Figure 2. 


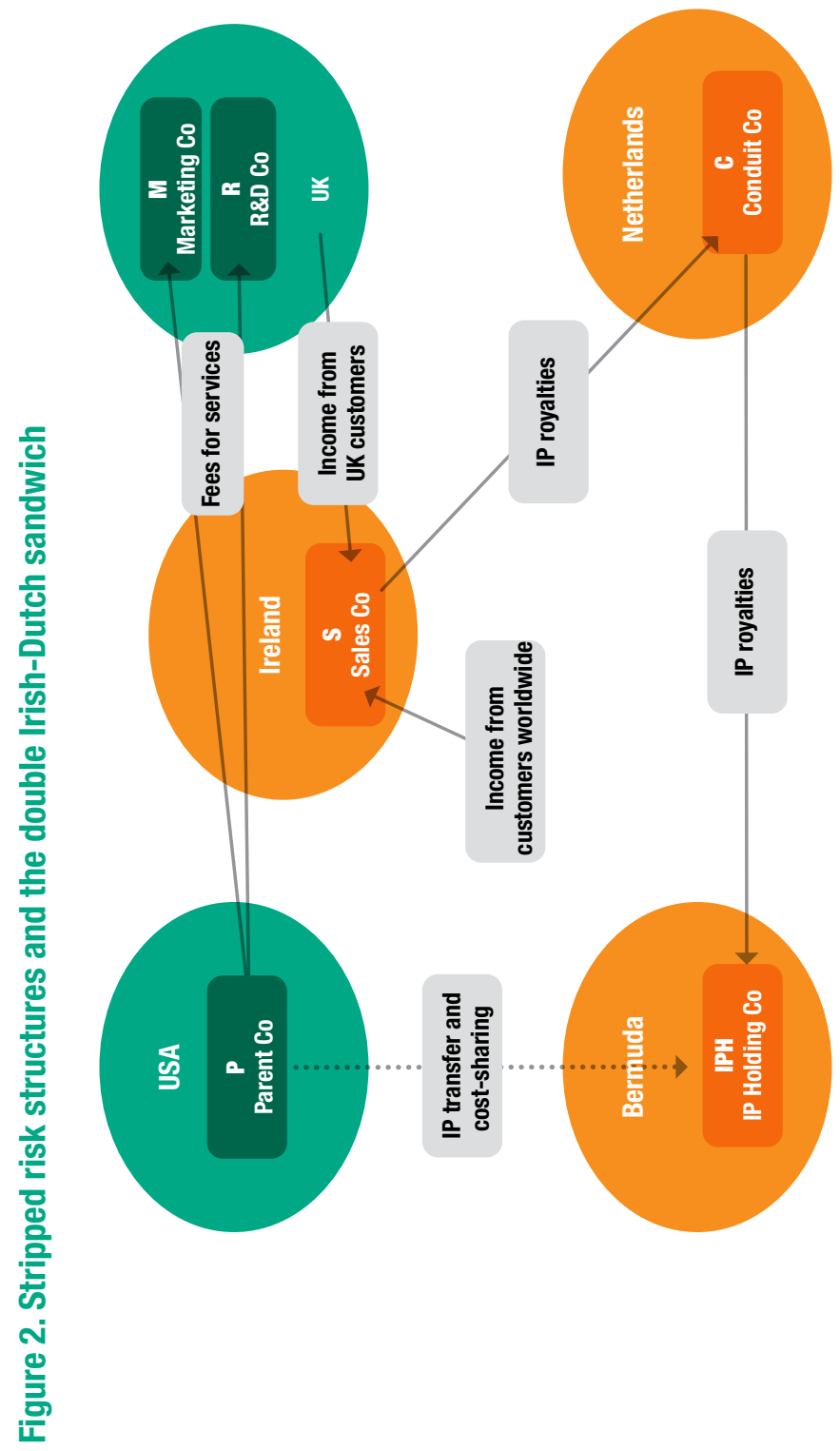

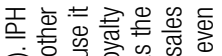
金定要

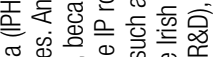
空

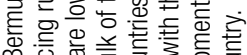

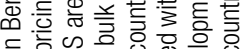

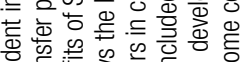

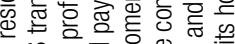

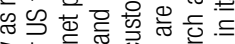

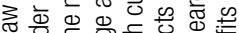

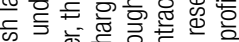

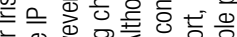

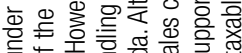

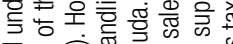
잉

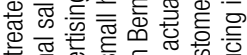

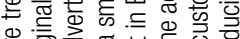

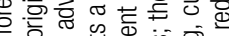

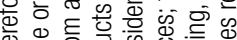

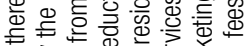

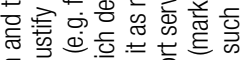

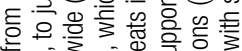
बi 흥

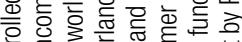
政

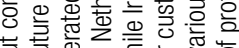

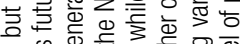

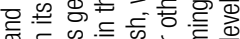
㐘 는

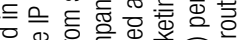

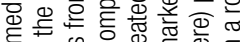

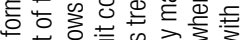

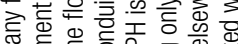

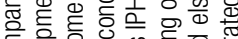
흥응 응

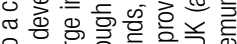

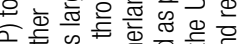

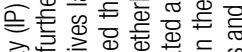

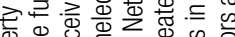
은

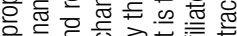

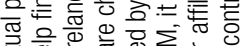

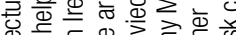
嵌

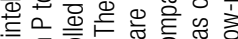

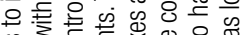

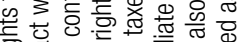
흔

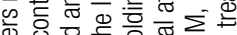

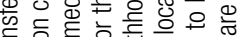

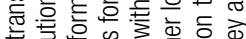

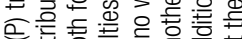

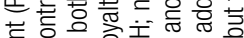

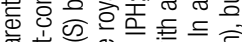
용

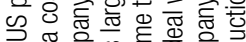

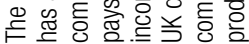


Such strategies were further facilitated by competition between countries to offer tax inducements to attract the supposedly high-value activities, e.g. Belgium for shareholding companies, the Netherlands for holding intellectual property rights, Luxembourg for finance, and Switzerland for commodities dealing and distribution management.

\subsection{Reform initiatives: the BEPS project}

Concern expressed especially by France and Germany about international tax avoidance and evasion led to an initiative in 1996 by the G7 leaders, who referred the problem to the OECD tax experts. The resulting report, Harmful Tax Competition (OECD, 1998) resulted only in a voluntary Code, monitored through peer review, and an initiative to improve bilateral exchange of information for tax purposes (AviYonah, 2009).

A decade later, the fiscal pressures resulting from the financial crisis of 2007-8 renewed these concerns, with a sharper spotlight on tax avoidance by TNCs, due to reports from civil society organizations and increasing media attention. Parliamentary inquiries proliferated (e.g. Bocquet and Dupont-Aignan, 2013; US Senate, 2013, 2014; UK Parliament, 2013), and influential academic studies analysed the problem of "stateless" or "homeless" income (Kleinbard, 2011; Wells and Lowell, 2011). The G20 leaders gave political support to an action plan on base erosion and profit shifting (BEPS), again initiated by the OECD's tax experts (Picciotto et al., 2017).

The G20 called for reforms to international tax rules to ensure that TNCs could be taxed "where economic activities occur and value is created" (G20, 2013). This implied a shift towards treating TNCs as unitary firms, and it was reinforced by the G20's request for "a common template for companies to report to tax administrations on their worldwide allocation of profits and tax". The OECD's tax experts initially assimilated this into the existing work on improving transfer pricing documentation, until it became clear that such country-by-country reports had a very different purpose: to provide each concerned tax authority with an overview of the firm as a whole.

Agreement on the form of this template was a major achievement of the BEPS project. It establishes, for the first time, a global system to provide information, listing all the affiliates of TNC corporate groups with turnover greater than €850 million, and quantifying their assets, employees, profits, and taxes paid in each country. A rigorous peer review procedure has been established to monitor implementation, and the system will provide a key tool for assessing whether and how far tax rules succeed in aligning profits and tax with the location of activities and value creation. Since the reports, at least for now, are to be available only to the 
relevant tax authorities, this assessment would guide only them, although plans are afoot to publish aggregated data. The availability of these reports, which may be extended to a wider range of TNCs and perhaps be made public when the system is reviewed in 2020, may prove transformative in the practice of TNC taxation.

However, much of the BEPS Action Plan outcomes resulted in a patch-up of existing rules. ${ }^{11}$ In particular, although the BEPS project resulted in extensive revision and expansion of the TPGs, this made them more complex and, in many respects, more obscure and difficult to apply. The starting point for transfer pricing audits is still the fictitious agreements between associated enterprises, even if unrelated parties would not have entered into such transactions. Although the revised TPGs now give tax authorities powers to disregard those transactions, to do so they must conduct a factual analysis to determine whether the actual conduct of the parties diverged from the formal contractual arrangements, and they must show that they were commercially irrational. The most authoritative account yet published, co-authored by a leading private practitioner and a former OECD Secretariat official responsible for the work on transfer pricing during most of the BEPS project, is understated but highly critical. It shows how, due to disagreements among participants in the BEPS project, the TPGs have become even more obscure, and concludes that the result has been to make the transfer pricing process "far more complex", mostly due to the "level of factual detail" now required for the functional analysis (Andrus and Collier, 2017, especially paras. 7.70-71).

\subsection{Continuing efforts}

The BEPS project is far from finished, as work continues on its most important and most difficult action point, the tax consequences of the digitalization of the economy, as well as monitoring the implementation of the agreed measures. Participation in this continuing work was opened up by the G20 to all States, creating an Inclusive Framework for BEPS, now with 116 members. This consolidates the OECD's domination of technical standard-setting and creates a de facto global tax body.

The implications of digitalization had been considered over a decade earlier by the OECD, when the concern was e-commerce. The resulting reports (OECD, 2005) concluded that information and communication technologies and the internet

\footnotetext{
${ }^{11}$ See Picciotto et al., 2017. The report on BEPS Actions 8-10 (OECD, 2015) included revisions to chapters I, II, VI, VII, and VIII of the TPGs, which were incorporated into the version issued in 2017, which is now over 600 pages long. All the final reports on the BEPS Action Plan are available at http:// www.oecd.org/ctp/beps-2015-final-reports.htm.
} 
would have profound effects on business models, but they did not require major changes to international tax rules, particularly the guidance on transfer pricing. This provided encouragement for digitalization to be further deployed to facilitate tax avoidance structures.

A decade later the issue was made Action 1 of the BEPS project. The 2015 report presented an analysis which stressed that digitalization was affecting the whole economy, so that its tax consequences could not adequately be dealt with by measures aimed at a demarcated digital sector. It made no recommendations, but only identified some interim measures which States might consider adopting, consistent with their international obligations. The OECD asked for, and was given, a further five years to produce a final report, but this work quickly became more urgent as several States moved to adopt measures and the European Commission put forward proposals for coordinated EU action. An interim report in March 2018 again argued that ring-fenced measures are not appropriate, stressed the progress made to adapt indirect taxes on sales to e-commerce, and analysed unilateral measures taken by States (OECD, 2018). A final report is expected before 2020.

This work has reopened consideration of the two basic concepts underlying international tax rules: the threshold for taxable presence, and the criteria for allocating the tax base. Proposals made on both these issues are far-reaching, and adequate solutions would require significant and comprehensive reforms. Yet, by the same token, reaching agreement on such a solution is a daunting task, especially as it requires consensus among a large number of States, for which tax remains central to their formal sovereignty. It is hard to see how this could come about unless the largest TNCs themselves accept that they have a responsibility as global citizens to contribute to a constructive solution.

\subsection{Alternative approaches}

Throughout the history of international taxation, it has been understood that the most effective approach to the allocation of taxable income of TNCs is to treat them in accordance with the business reality that they are unitary firms. Three methods have been put forward that adopt such an approach (for further details, see Picciotto, 2017, ch. 2). Each has advantages and disadvantages, but any of the three would provide a sounder foundation than the current dominant approach.

One is residence-based worldwide taxation. This would apply home country tax directly on a current basis to the consolidated worldwide profits of a corporate group, but with a full credit for foreign taxes paid. This would in effect treat all foreign affiliates on a full-inclusion basis as CFCs. This was the approach proposed in the US, introduced in much weakened form in 1962, and which some commentators continue to advocate (e.g. Fleming et al., 2014). Indeed, strengthening CFC rules 
was one item in the BEPS Action Plan, supported by the US, but States could agree only on very modest recommendations. However, the US tax reform of 2017 largely abandoned its CFC regime, moving to a primarily territorial system, but with targeted measures against erosion of the home country tax base. Other States have also moved away from this approach, though some still retain it (for example, Brazil). It also faces significant practical difficulties, particularly in specifying the home country, which makes it easier to avoid by moving corporate headquarters to low-tax jurisdictions.

A second, which was actively debated in the US from mid-2016 to late 2017, is the destination-based cash flow tax. This would in effect be a unitary approach, since internal transfers within a corporate group are ignored: the tax base is defined in terms of sales to third parties, and it is apportioned among the countries of destination of those sales. However, the reasons for this proposal seem to have been peculiar to the US (the US has no federal value added tax, and this would be economically similar to such a tax), and despite influential support the idea now seems to have been largely abandoned (Shaviro, 2018).

The most comprehensive approach would be unitary taxation with formulary apportionment. As mentioned above, "fractional apportionment" was applied by some States from the beginning and is still permitted under many tax treaties, although firmly rejected by the OECD Guidelines. It has also long been used within some federal systems, notably in the US, and is now proposed for regional adoption within the EU, in the form of a common consolidated corporate tax base. The superior conceptual basis for this approach is widely accepted. The main objection is the political difficulty of reaching agreement among States on its key components: the definition of the tax base and the formula for allocation.

In turn, major obstacles to such a political agreement are clearly the economic power of TNCs and their role as transnational actors. The public concerns about their international tax practices that emerged following the financial crisis has caused them reputational damage, which prompted politicians to proclaim the need for international solutions. This has resulted in a tightening of rules around the world, which is likely to greatly increase the costs of both tax compliance and tax planning. It remains to be seen whether these factors will prompt TNCs to lend active support to a search for a comprehensive approach based on unitary taxation.

\section{Conclusions: integrating tax into the understanding of TNCs}

It seems clear that the continual claims of TNCs that they simply obey the laws in every country where they do business are disingenuous. As global actors, they are highly effective at lobbying both at the national level, and even more so in 
international fora, to obtain rules that they consider suitable. From this perspective, they have been highly successful at securing a framework for international tax that provides strong protections against "double taxation" while leaving considerable leeway and loopholes that can be exploited for tax avoidance. Thus, they devote considerable resources, both to helping to formulate the rules and to devising strategies to shape the interpretation and application of those rules.

More specifically, the international tax avoidance strategies outlined here give many of the largest TNCs considerable competitive advantage over purely national firms, as well as the large universe of TNCs that are small or less willing to devote resources to international tax planning. These strategies have the effect of ensuring low effective tax rates on retained earnings, which provide large pools of cash under the control of senior managers and executives. These resources can be used for further expansion, often through acquisitions, which reinforce the oligopolistic positions of these giant firms. They are also used for share buybacks, which have contributed to the "financialization" of the large corporation. This has been beneficial to the top executives whose remuneration has been substantially dependent on the share price, but damaging to productivity and employment (Lazonick, 2012-13, 2014).

The example of international tax also raises broader questions for the understanding of both the dynamics behind the growth of TNCs and the forms they have taken. As regards the reasons for their growth, the theories of "internalization" pointed to the balance between the problems posed by managing large firms with worldwide operations and the economic advantages derived from economies of scope and scale, and business synergies. It seems, however, as pointed out by Grazia letto-Gillies (2012, ch. 14), that the exploitation and management of regulatory differences have also been an important factor in the growth of TNCs, especially since the 1980s. Strategies for international tax avoidance are an important type of such regulatory arbitrage. As explained in this paper, these strategies go far beyond the manipulation of transfer prices.

For some firms, tax avoidance and regulatory arbitrage have become major elements in their growth dynamic. As the tax rules on allocation of income became focused on the pricing of transactions, the business literature began to consider tax minimization as one of the factors in setting transfer pricing policies, while noting that what can be considered an arm's length price is a grey area (e.g. Barrett, 1977). Increasingly, tax considerations became an important factor in determining transfer pricing, rather than the concerns of optimising the firms' business strategy and performance. Now researchers construct complex models to try to take all factors into account (e.g. de Matta and Miller, 2015; Gao and Zhao, 2015). This assumes that managers of profit centres are judged on post-tax returns, which would encourage them to build tax avoidance as well as operational factors into 
their decision-making. Alternatively, of course, firms can separate managerial incentive structures from their central tax planning strategies. ${ }^{12}$

A leader in adopting an aggressive tax planning strategy was General Electric (GE) in the last decade of the twentieth century. ${ }^{13}$ Under a former US Treasury official, appointed in 1988, GE built an international tax department of close to 1000 specialists, many of them former government officials (Kocienewski, 2011; Sloan and Gerth, 2011). Closely tied to the creation of GE Capital as its financing arm, GE's tax strategy was integrated with its business decision-making, and combined lobbying for suitable tax rules with devising structures to minimize its taxes worldwide (Gerth and Sloan, 2011). This clearly played a key part in fuelling a range of acquisitions which built GE, under CEOs Jack Welch and then Jeff Immelt, into a global conglomerate. GE even claimed to combine performance with corporate responsibility, at least by avoiding major scandals such as occurred at Enron and Walmart. This was perhaps attributable to the skills of its legal department which, under Ben Heineman in the same period as Samuels, grew even larger than the tax department, with over 1200 lawyers in over 100 countries (Gordon, 2017: 1754). One leading commentator argues that this suggests that in-house lawyers may be more effective in shielding a firm from reputational damage than as guardians of responsible corporate behaviour (Gordon, 2017: 1760).

After a decade of erratic performance, the wheels finally came off this financedriven growth when GE Capital was hit by the financial crisis (Colvin, 2018), leading to a decision to divest it. GE outsourced its tax planning functions by transferring some two-thirds of its tax team to PwC (Schwanke, 2017), joining what is claimed to be one of the world's largest corporate tax networks of 41,000 specialists in 157 countries (PwC, 2017). This does not necessarily signal a major shift in GE's tax planning strategy, but rather attests to the ability of $\mathrm{PwC}$ and the other Big 4 accounting and consultancy firms to offer such services to TNCs more generally.

Thus, in addition to contributing to the global power of the largest TNCs, tax considerations have also affected the structures they have adopted. Tax avoidance was one element of the emergence of the system of offshore finance and secrecy since the late 1950s that was closely tied to the post-war expansion of TNCs, and it was later a key factor in financialization (Hampton and Abbott, 1999; Picciotto, 2011, ch. 7). Tax and financial engineering are clearly central to the strategic management of large TNCs. More recently, the encouragement provided by the

\footnotetext{
${ }^{12}$ This topic seems under-researched, I am not aware of any recent surveys of management practices comparable to that of Eccles (1980); the issue is discussed in the UN Manual (UN 2017, section A4).

${ }^{13}$ Although GE was exceptional, others also restructured their operations around tax minimization strategies of different kinds, often devised by, or in conjunction with, one of the Big Four, e.g. Caterpillar (US Senate, 2014).
} 
ALP for functional fragmentation seems to have contributed to the increased importance of the management of global value chains. These factors have driven the restructuring not only of individual TNCs, but whole industries. For example, tax and regulatory avoidance and evasion were key strategies for Marc Rich in building Glencore, which together with other trading firms such as Trafigura and Vitol, became dominant in the extractive industries.

At the centre of today's debate about the need for international tax reform are the large internet-based companies. Their growth and dominance can be attributed not just to technological leadership, but to their ability to use tax avoidance strategies to generate lightly taxed revenues to finance their expansion. This has involved creating new business models disrupting a range of sectors including travel and tourism, retail, taxi services and entertainment (Casella and Formenti, 2018). A significant factor in their growth is clearly their ability to avoid not only tax in host countries, but also other regulation such as licensing requirements and employment laws.

Analysis of these changes clearly requires the integration of a greater understanding of international tax into the study of TNCs. 


\section{References}

Abdel-Khalik, A. R., and Lusk, E. J. (1974). "Transfer Pricing - a Synthesis", The Accounting Review 49, pp. 8-23.

Adler, E., and Haas, P. M. (1992). "Conclusion: Epistemic Communities, World Order, and the Creation of a Reflective Research Program" International Organization, 46, pp. 367-390.

Adler, E., and Bernstein, S. (2005). "Knowledge in Power: The Epistemic Construction of Global Governance", in M. N. Barnett and R. Duvall, eds., Power in Global Governance (Cambridge: Cambridge UP), pp. 294-318.

Andrus, J., and Collier, R. (2017). Transfer Pricing and the Arm's Length Principle After BEPS (Oxford: Oxford University Press).

Anon. (1976). "Multinational Corporations and Income Allocation under Section 482 of the Internal Revenue Code", Harvard Law Review 89, pp. 1202-1238.

Avi-Yonah, R. S. (1995). "The Rise and Fall of Arm's Length: A Study in the Evolution of U.S. International Taxation”, Virginia Tax Review 15, pp. 89-159.

Avi-Yonah, R. (2009). "The OECD Harmful Tax Competition Report: A Retrospective after a Decade", Brooklyn Journal of International Law 34, pp. 783-795.

Avi-Yonah, R. S., and Tinhaga, Z. P. (2014). "Unitary Taxation and International Tax Rules", International Centre for Tax and Development, ICTD Working Paper 26.

Ball, G. W. (1967). "Cosmocorp - The Importance of Being Stateless", Columbia Journal of World Business, 2, p. 25.

Ball, G. W. (1975). Global Companies: The Political Economy of World Business (Englewood Cliffs, N.J.: Prentice-Hall).

Barrett, M. E. (1977). "Case of the Tangled Transfer Price", Harvard Business Review 55, pp. 20-32.

Blumberg, P. I. (1983). The Law of Corporate Groups (Boston: Little, Brown).

Bocquet, A., and Dupont-Aignan, N. (2013). Lutte contre les paradis fiscaux : si l'on passait des paroles aux actes. Doc. 1423, Assemblée Nationale de France.

Casella, B., and Formenti, L. (2018). "FDI in the Digital Economy: A Shift to Asset-Light International Footprints", Transnational Corporations, 25(1), pp. 101-130.

Colvin, G. (2018). "What the Hell Happened at GE?" Fortune, 24 May.

de Matta, R., and Miller, T. (2015). "Formation of a strategic manufacturing and distribution network with transfer prices", European Journal of Operational Research, 241, pp. 435-448.

Dezalay, Y., and Garth, B. (2001). The Internationalization of Palace Wars: Lawyers, Economists, and the Contest to Transform Latin American States (Chicago: University of Chicago Press).

Durst, M. C., and Culbertson, R.E. (2003). "Clearing Away the Sand; Retrospective Methods and Prospective Documentation in Transfer Pricing Today", NYU Tax Law Review 57, pp. 37-136.

Durst, M. C. (2016). "Developing Country Revenue Mobilization: A Proposal to Modify the 'Transactional Net Margin' Transfer Pricing Method". ICTD Working Paper 44, International Centre for Tax and Development. 
Eccles, R. G. (1985). The Transfer Price Problem. A Theory for Practice, (Cambridge, Mass.: Lexington Books).

Fleming Jr., J. C., Peroni, R. J., and Shay, S. E. (2014). "Formulary Apportionment in the U.S. International Income Tax System: Putting Lipstick on a Pig", Michigan Journal International Law 36, pp. 1-57.

France, Ministry of Finance (2013). Comparaison internationale sur la lutte contre l'évasion fiscale via les échanges économiques et financiers intra-groupe, Inspection Générale des Finances, Note 2012-M-032-03.

G20 (2013). Tax Annex to St Petersburg Declaration, September, available at https://www. oecd.org/g20/summits/saint-petersburg/Tax-Annex-St-Petersburg-G20-LeadersDeclaration.pdf

Gao, L., and Zhao, X. (2015). "Determining intra-company transfer pricing for multinational corporations", International Journal of Production Economics 168, pp. 340-350.

Gerth, J., and Sloan, A. (2011). "5 Ways GE Plays the Tax Game”, Pro Publica/Fortune, 4 April.

Gordon, R. W. (2017). “The Return of the Lawyer-Statesman?”, Stanford Law Review, 69, pp. 1731-1764.

Grondona, V., and Knobel, A. (2017). "Transfer Pricing in Argentina, 1932-2015". ICTD Working Paper 63, International Centre for Tax and Development.

Hadden, T. (1993). "Regulating Corporate Groups: An International Perspective", in J. McCahery, S. Picciotto and C. Scott, eds., Corporate Control and Accountability (Oxford: Clarendon Press), pp 343-369.

Hampton, M. P., and Abbott, J. P. (eds.). (1999). Offshore Finance Centres and Tax Havens. The Rise of Global Capital (Basingstoke: Macmillan).

Hirshleifer, J. (1956). "On the Economics of Transfer Pricing", Journal of Business 29, pp. 172-184.

letto-Gillies, G. (2012). Transnational Corporations and International Production : Concepts, Theories and Effects (Cheltenham: Edward Elgar).

Jogarajan, S. (2018). Double Taxation and the League of Nations (Cambridge: Cambridge University Press).

Kleinbard, E. D. (2011). "Stateless Income", Florida Tax Review 9, pp. 700-773.

Knightley, P. (1993). The Rise and Fall of the House of Vestey, (London: Warner).

Kocienewski, D. (2011). "G.E.'s Strategies Let It Avoid Taxes Altogether", New York Times, 14 March.

Lall, S. (1973). "Transfer Pricing by Multinational Manufacturing Firms", Oxford Bulletin of Economics and Statistics, 35, pp. 182-191.

Langbein, S. I. (1986). "The Unitary Method and the Myth of Arm's Length”, Tax Notes 30, pp. 625-681.

Langbein, S. I. (2010). "Cognitive Capture, Parliamentary Parentheses, and the Rise of Fractional Apportionment", Tax Management International Journal 39, pp. 567-605. 
Lazonick, W. (2012-2013). "The Financialization of the U.S. Corporation: What has been Lost, and How It can be Regained", Seattle University Law Review, 36, pp. 857-909.

Lazonick, W. (2014). "Profits Without Prosperity", Harvard Business Review, 92, pp. 46-55 League of Nations (1933). Taxation of Foreign and National Enterprises. Volume 4: Methods of Allocating Taxable Income (Geneva: League of Nations). Available at http://setis. library.usyd.edu.au/pubotbin/toccer-new?id=cartaxa.sgml\&tag=law\&images=acdp/ gifs\&data=/usr/ot\&part=0

League of Nations (1935). Report of Fiscal Committee to Council on the Fifth Session of the Committee, Document C.252.M.124 1935 IIA. Available at http://www.uni-heidelberg. de/institute/fak2/mussgnug/historyoftaxdocuments/normtexte/voelkerrecht/V00016.pdf

MacKenzie, D. (2006). An Engine, Not a Camera: How Financial Models Shape Markets (Cambridge, Mass.: MIT Press).

OECD (1967a). Report on the Apportionment of Profits of Permanent Establishments and Associated Enterprises, document FC/WP7 (67) 1 (Paris: Organisation for Economic Cooperation and Development).

OECD (1967b). Working Party 21, Third Report on Tax Avoidance through the Improper Use or Abuse of Tax Conventions, document FC/WP21 (67)1 (Paris: Organisation for Economic Cooperation and Development).

OECD (1979). Transfer Pricing and Multinational Enterprises (Paris: Organisation for Economic Cooperation and Development).

OECD (1995). Transfer Pricing Guidelines for Multinational Enterprises and Tax Administrations (Paris: Organisation for Economic Cooperation and Development).

OECD (1998). Harmful Tax Competition. An Emerging Global Issue (Paris: Organization for Economic Cooperation and Development).

OECD (2005). E-commerce: Transfer Pricing and Business Profits Taxation, OECD Tax Policy Studies No. 10 (Paris: Organisation for Economic Cooperation and Development).

OECD (2013). Action Plan on Base Erosion and Profit Shifting (Paris: Organisation for Economic Cooperation and Development).

OECD (2017). OECD Transfer Pricing Guidelines for Multinational Enterprises and Tax Administrations (Paris: Organisation for Economic Cooperation and Development).

OECD (2018). Tax Challenges Arising from Digitalisation - Interim Report (Paris: Organisation for Economic Cooperation and Development).

Picciotto, S. (1983). "Jurisdictional Conflicts, International Law and the International State System", International Journal of the Sociology of Law, 11, pp. 11-40.

Picciotto, S. (1992). International Business Taxation (London: Weidenfeld \& Nicolson). Available at http://taxjustice.blogspot.be/2013/06/international-business-taxation.html.

Picciotto, S. (2011). Regulating Global Corporate Capitalism (Cambridge: Cambridge University Press).

Picciotto, S. (2015). "Indeterminacy, Complexity, Technocracy and the Reform of International Corporate Taxation", Social \& Legal Studies 24, pp. 165-184.

Picciotto, S. (2016). "International Tax Disputes: Between Supranational Administration and Adjudication". ICTD working paper 55, International Centre for Tax and Development. 
Picciotto, S. (ed.) (2017). Taxing Multinational Enterprises as Unitary Firms, (Brighton: International Centre for Tax and Development).

Picciotto, S., with Gallardo, A., Kadet, J., Henn, M., and Villanueva, M. (2017). The G20 and the "Base Erosion and Profit Shifting (BEPS) Project" (Bonn: Deutsches Institut für Entwicklungspolitik).

Picciotto, S. (2018). "Problems of Transfer Pricing and Possibilities for Simplification". ICTD working paper forthcoming, International Centre for Tax and Development.

PwC (2017). "Global Enterprise Tax Solutions Team Comprised of Former GE Tax Group", 12 January.

Schwanke, A. (2017). "GE/PwC deal advances trend to outsource tax functions", International Tax Review, 28 February.

Shaviro, D. N. (2018). "Goodbye to All That? A Requiem for the Destination-Based Cash Flow Tax", NYU School of Law, Public Law Research Paper No. 18-12, available at https:// ssrn.com/abstract=3116406.

Sloan, A., and Gerth, J. (2011). "The truth about GE's tax bill”, Fortune/ProPublica, 4 April.

Ting, A. (2013). The Taxation of Corporate Groups under Consolidation: An International Comparison (Cambridge: Cambridge University Press).

UK Monopolies Commission (1973). Chlordiazepoxide and Diazepam.

UK Parliament (2013). Tax Avoidance - Google, document HC 112 (London: House of Commons, Committee of Public Accounts).

UN (1974). The Impact of Multinational Corporations on Development and on International Relations (New York: United Nations). Available at http://www.jstor.org/stable/20691289

UN (2017). Practical Manual on Transfer Pricing for Developing Countries (New York: United Nations).

UNCTAD (2016). World Investment Report. Investor Nationality: Policy Challenges (Geneva, United Nations).

US GAO. (1981). "IRS Could Better Protect US Tax Interests in Determining the Income of Multinational Corporations" (Washington D.C.: General Accounting Office).

US Senate (2013). Offshore Profit Shifting and the U.S. Tax Code. Part 1 - Microsoft and Hewlett Packard. Part 2 - Apple, Inc., Hearings before the Permanent Subcommittee on Investigations of the Committee on Homeland Security and Governmental Affairs, S. Hrg. 112-781 (Washington, D.C.: U.S. Congress).

US Senate (2014). Caterpillar's Offshore Tax Strategy. Permanent Subcommittee on Investigations (Washington, D.C.: U.S Congress).

US Treasury (1973). Summary Study of International Cases Involving s.482 of the Internal Revenue Code (Washington D.C., U.S. Treasury). Reprinted in Murray, R. (1981). Multinationals Beyond the Market. Intra-Firm Trade and the Control of Transfer Pricing (Brighton: Harvester/Murray).

Wells, B., and Lowell, C. (2011). "Tax Base Erosion and Homeless Income: Collection at Source is the Linchpin”, Tax Law Review, 65, pp. 535-617. 
